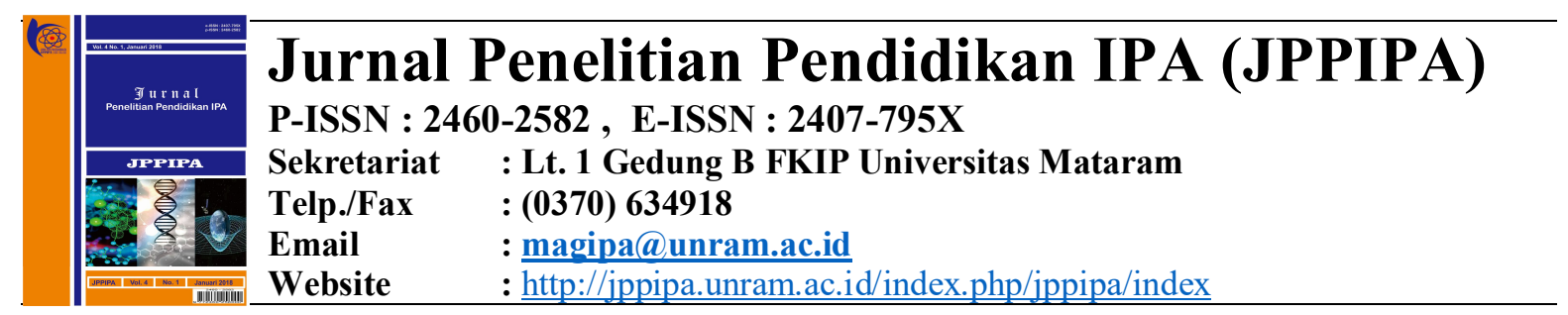

\title{
PENGEMBANGAN PERANGKAT PEMBELAJARAN BIOLOGI BERBASIS INKUIRI TERBIMBING (PPBIT) DALAM MENINGKATKAN KEMAMPUAN BERARGUMEN SISWA
}

\author{
Dewi Seprianingsih ${ }^{1}$, Wahab Jufri ${ }^{2}$, Jamaluddin ${ }^{2}$ \\ Program Studi Magister Pendidikan IPA, Program Pascasarjana Universitas Mataram ${ }^{123}$ \\ Email: dewi.seprianingsih@gmail.com
}

\begin{tabular}{|c|c|}
\hline Key Words & Abstract \\
\hline $\begin{array}{l}\text { PPBIT, } \\
\text { Argument }\end{array}$ & $\begin{array}{l}\text { This study was aimed to develop inquiry-based learning tools (PPBIT) and } \\
\text { analyzed its effectiveness in developing the ability to argue of students at } \\
\text { SMAN } 2 \text { Taliwang-West Sumbawa. PPBIT was carried out by applying } 4 D \\
\text { procedure. Then, pretest posttest control group design also completely } \\
\text { concerned in determining the effectiveness of PPBIT. There were } 66 \text { students } \\
\text { as the sample which was scattered from two classes and was selected by } \\
\text { using purposive sampling technique. The results showed that PPBIT was } \\
\text { appropriately to be used for students argumentation skills' activities by an } \\
\text { average of feasibility syllabus } 78.71 \% \text {, RPP 83.5, LKITS } 75 \% \text {, and } \\
\text { Instruments KB } 80.25 \% \text {, and effective in improving the ability to argue the } \\
\text { class X SMAN } 2 \text { Taliwang, particularly on the subject of environmental } \\
\text { pollution and recycling of waste by the average score of the students' ability } \\
\text { from } 48.22 \text { up to } 85.08 \text {. }\end{array}$ \\
\hline Kata Kunci & Abstrak \\
\hline $\begin{array}{l}P P B I T, \\
\text { Argumen }\end{array}$ & $\begin{array}{l}\text { Penelitian ini bertujuan untuk mengembangkan perangkat pembelajaran } \\
\text { berbasis inkuiri (PPBIT) dan menganalisis efektivitasnya dalam } \\
\text { meningkatkan kemampuan berargumen siswa SMAN } 2 \text { Taliwang-Sumbawa } \\
\text { Barat. PPBIT dilaksanakan dengan mengacu pada prosedur 4D. Untuk } \\
\text { mengetahui efektivitas PPBIT selanjutnya dilakukan penelitian quasi } \\
\text { eksperimen dengan rancangan pretes posttes control group desain. Sampel } \\
\text { penelitian berjumlah } 66 \text { orang yang tersebar dalam dua kelas yang dipilih } \\
\text { dengan teknik purposive sampling. Hasil penelitian menunjukkan bahwa } \\
\text { PPBIT layak digunakan dengan rata-rata kelayakan silabus } 78.71 \% \text {, RPP } \\
83.5 \text {, LKITS 75\%, dan Instrumen KB 80.25\%, dan efektif dalam } \\
\text { meningkatkan kemampuan berargumen siswa kelas X SMAN } 2 \text { Taliwang, } \\
\text { pada materi pencemaran lingkungan dan daur ulang limbah dengan skor rata- } \\
\text { rata kemampuan berargumen siswa dari } 48.22 \text { menjadi } 85,08 \text {. }\end{array}$ \\
\hline
\end{tabular}

\section{PENDAHULUAN}

Menurut Permendiknas No. 22 tahun

2006 tujuan pembelajaran, yaitu mengembangkan pengalaman untuk dapat mengajukan dan menguji hipotesis melalui percobaan, serta mengkomunikasikan hasil percobaan secara lisan dan tertulis, dan mengembangkan kemampuan berpikir analitis, induktif, dan deduktif dengan menggunakan konsep dan prinsip biologi, Laporan TIMSS (The Trends in International Mathematics and Science 
Study) tahun 2011, menunjukkan bahwa rangking anak Indonesia dalam bidang sains menduduki posisi ke 42 dari 45 negara dengan skor rata-rata siswa Indonesia berada dibawah rata-rata peserta TIMS negara lain. Anak-anak Indonesia masih tidak mampu dalam hal antara lain: (1) menunjukkan beberapa konsep yang abstrak dan kompleks dalam sains, (2) memahami kompleksitas makhluk hidup dan hubungan mereka dengan lingkungannya, berkaitan dengan lemahnya kemampuan siswa dalam berargumen.

Kenyataan di lapangan bahwa, kemampuan berargumen yang dimiliki siswa masih relatif rendah. Hasil observasi dan wawancara dengan guru di SMA Negeri 2 Taliwang menunjukkan bahwa siswa masih kurang aktif dalam mengajukan pertanyaan, kurang berani dalam berpendapat dan menjawab pertanyaan dari masalah yang diberikan oleh guru. Sehingga iswa menjadi pasif dalam belajar dikelas, siswa umumnya kurang dilibatkan dalam membangun kecakapan berpikirnya. Kegiatan belajar siswa yang belum optimal ini, akan mempengaruhi hasil belajar siswa, jika siswa dibiasakan dalam melatih kecakapan berpikirnya baik secara tulisan maupun lisan, maka kecakapan berpikir siswa akan bagus dan terarah, terutama dalam memberikan pendapat atau berargumen.

Menurut pendapat Fisher (2009:234) bahwa Argumentasi adalah kebenaran atau ketidakbenaran yang dibuktikan dari sebuah pernyataan. Sejalan dengan pendapat Bell (2007) argumentasi juga diartikan pula sebagai eksplorasi yang sistematis dari suatu konfrontasi teoritis melalui koordinasi bukti yang menggambarkan hasil observasi atau hasil eksperimen tentang fenomena alam.

Berdasarkan penelitian Dusch and Orbone (2002) dalam Roshayanti (2013), memberikan contoh argumen dalam pembelajaran sains, yakni guru memberikan eksplansi ilmiah kepada siswa untuk membantu mereka memahami eksplansi ilmiah tersebut sebagai suatu alasan (reasoning). Senada dengan pendapat
Toulmin, dkk (1979) dalam Setianingsih (2008) bahwa Toulmin's Argument Pattern (TAP) atau logika Toulmin mengelompokkan sifat argumen dalam enam elemen, yaitu : 1) penyatuan posisi (Claim), 2) data (Grounds), 3) jaminan (warrant), 4) pendukung (backing), 5) keterangan Modalitas (modal qualifier) dan 6) kondisi pengecualiaan (Possible rebuttal).

Penelitian Setianingsih (2008), Hartatiana \& Darmawijoyo (2011) juga menjelaskan bahwa model pembelajaran berdasarkan logika Toulmin dapat meningkatkan kemampuan berpikir kritis dan memecahkan masalah yang dikembangkan melalui menulis argumentatif.

Salah satu model pembelajaran yang dapat digunakan dalam membantu memudahkan siswa dalam menemukan penyelesaian masalah sesuai dengan pengalaman siswa adalah menggunakan model pembelajaran inkuiri terbimbing. Model ini lebih efektif membantu dalam melatih dan membimbing siswa dalam menemukan konsep yang konkrit dan dapat membangun pola berpikir yang tinggi. Penelitian Sampson dan Gerbiano (2010), juga menemukan bahwa melalui model pembelajaran yang dikembangkan oleh guru seperti model two instruksional dapat membangkitkan siswa dalam mengemukakan pendapat untuk menumbuhkan pemahaman konsep dan kemampuan berargumentasi yang dapat diterapkan di kelas.

Hussains et al. (2011), juga menunjukkan bahwa pembelajaran menggunakan model inkuiri lebih efektif daripada pembelajaran menggunakan model pembelajaran konvensional (ceramah atau hanya dari buku paket saja). Eggen dan Kauchak (2012), juga meyatakan bahwa perencanaan pelajaran menggunakan model inkuiri melibatkan dua langkah penting, yaitu: (a) Mengidentifikasi pertanyaan atau masalah, dan (b) Mengumpulkan data. 
Tujuan penelitian ini (1) untuk mengembangkan perangkat pembelajaran berbasis inkuiri (PPBIT), dan (2) untuk menganalisis efektivitas penerapan dalam mengembangkan kemampuan berargumen.

\section{METODOLOGI}

Penelitian ini termasuk penelitian pengembangan yang mengacu pada prosedur 4D. Sampel penelitian diambil melalui teknik purposive sampling, terpilih 66 orng yang tersebar kedalam dua kelas.

Tahap 4D, terdiri dari tahapan define, design, develop, dan disseminate. Tahap define Tahap ini, terbagi menjadi lima bagian yaitu siswa, analisisis permasalahan, analisis tugas, analisis konsep dan analisis tujuan pembelajaran..

Analisis permasalahan ini bertujuan menetapkan permasalahan-permasalahan pada sekolah tersebut melalui observasi. Kompetensi Dasar dalam penelitian ini, adalah: menganalisis pencemaran lingkungan dan daur ulang limbah. Analisis siswa, dilakukan untuk mengetahui latar belakang siswa, pengetahuan awal siswa dan pengalaman siswa berpikir secara inkuiri dan membiasakan siswa dalam berpikir kritis. Analisis tugas terkait pada siswa mengerjakan Lembar Kegiatan Inkuiri TerbimbingSiswa (LKITS) dengan fenomena pencemaran lingkungan dan daur ulang limbah yang ada di sekitar lingkungan siswa. Analisis konsep yaitu mengdentifikasi konsep-konsep yang disusun secara sistematis terhadap konsep yang akan diajarkan. Konsep yang diberikan dapat disampaikan dengan peta konsep dan disertai contoh-contoh yang akan memudahkan siswa dalam memahami materi pelajaran.

Tahap design, bertujuan untuk menyiapkan perangkat pembelajaran. Perangkat pebelajaran dalam penelitian ini meliputi: silabus, RPP, LKITS dan instrumen kemampuan berargumen, instrumen kemampuan berargumen.

Tahap develop, berupa validasi oleh Tim Ahli dan uji coba dari hasil pengembangan perangkat pembelajaran berbasis inkuiri terbimbing (PPBIT). Validator PPBIT ini terdiri dari tiga dosen ahli pendidikan. Aspek yang nilai meliputi kelayakan isi, teknik penyajian, dan tata bahasa PPBIT. Instrumen diujicoba lebih lanjut bila kelayakan instrumen berada pada kategori minimal tinggi, yang disajikan pada Tabel 1.

Tabel 1. Kriteria Kelayakan Instrumen

\begin{tabular}{ccc}
\hline No & Nilai Persentase & $\begin{array}{c}\text { Kelayakan } \\
\text { Instrumen }\end{array}$ \\
\hline 1 & $80-100$ & Sangat tinggi \\
\hline 2 & $60-80$ & Tinggi \\
\hline 3 & $40-60$ & Cukup \\
\hline 4 & $20-40$ & Rendah \\
\hline 5 & $00-20$ & Sangat rendah \\
\hline \multicolumn{3}{c}{ (Sumber: Arikunto, 2009) } \\
& Tahap terakhir adalah tahap
\end{tabular}

Disseminate, dilakukan melalui ujicoba terbatas pada SMAN 2 Taliwang dan menerbitkan hasil penelitian.

Rancangan yang digunakan dalam penelitian eksperimen ini adalahpretestposttest control group design. Rancangan penelitian disajikan pada Tabel 2 berikut ini: Tabel 2. Rancangan Penelitian Tipe PretestPosttest Control Group.

\begin{tabular}{cccc}
\hline Kelas & $\begin{array}{c}\text { Pre- } \\
\text { Test }\end{array}$ & Perlakuan & $\begin{array}{c}\text { Post- } \\
\text { Test }\end{array}$ \\
\hline $\mathrm{K}_{\mathrm{a}}$ & $\mathrm{T}_{1}$ & $\mathrm{X}$ & $\mathrm{T}_{3}$ \\
\hline $\mathrm{K}_{\mathrm{b}}$ & $\mathrm{T}_{2}$ & - & $\mathrm{T} 4$ \\
\hline
\end{tabular}

Untuk melihat perbedaan peningkatan hasil belajar antara siswa yang mengikuti pembelajaran PPBIT terjadi atau tidak dengan menggunakan rumus gain score sebagai berikut:

$$
\langle g\rangle=\frac{\left\langle S_{\text {post }}\right\rangle-\left\langle S_{\text {pre }}\right\rangle}{100 \%-\left\langle S_{\text {pre }}\right\rangle}
$$

(Sumber: Riduwan, 2006)

Kriteria perolehan dikonversikan kedalam kriteria berikut:

Tabel 3. Kriteria Perolehan N-gain

\begin{tabular}{ll}
\hline $\mathrm{N}$-gain & Keterangan \\
\hline$>0,70$ & Tinggi \\
$0,30 \leq \mathrm{N}-$ gain $\geq 0,70$ & Sedang \\
$<0,30$ & Rendah \\
\hline Untuk mengetahui efektifitas \\
pemberian perlakuan PPBIT dapat
\end{tabular}


meningkatkan kemampuan berargumen diolah melalui uji perbedaan skor rerata posttest dan pretes menggunakan uji t dua pihak (Sugiyono, 2012).

$$
t=\frac{\overline{X_{1}}-\overline{X_{2}}}{\sqrt{\frac{\left(n_{1}-1\right) \cdot S_{1}{ }^{2}+\left(n_{2}-1\right) \cdot S_{2}{ }^{2}}{n_{1}+n_{2}-2} \cdot\left(\frac{1}{n_{1}}+\frac{1}{n_{2}}\right)}}
$$

\section{HASIL DAN PEMBAHASAN}

Hasil rekapitulasi perangkat pembelajaran berbasis inkuiri (PPBIT) berdasarkan kelayakan disajikan pada Tabel berikut ini:

Tabel 4. Rekapitulasi Kelayakan PPBIT

\begin{tabular}{lcl}
\hline PPBIT & $\begin{array}{c}\text { Persentase } \\
(\%)\end{array}$ & Kelayakan \\
\hline Silabus & 78.71 & Tinggi \\
\hline RPP & 83.5 & Sangat tinggi \\
\hline LKITS & 75 & Tinggi \\
\hline $\begin{array}{l}\text { Instrumen } \\
\text { kemampuan } \\
\text { berargumen }\end{array}$ & 80.25 & Sangat tinggi \\
\hline
\end{tabular}

Tes kemampuan berargumen yang telah diujicobakan pada siswa kelas X di SMA Negeri 2 Taliwang Sumbawa Barat, dengan butir soal berjumlah 8 soal.. Perbandingan hasil dari pretest dan posttes pada kelas eksperimen dan kelas kontrol dapat disajikan pada gambar dibawah ini:

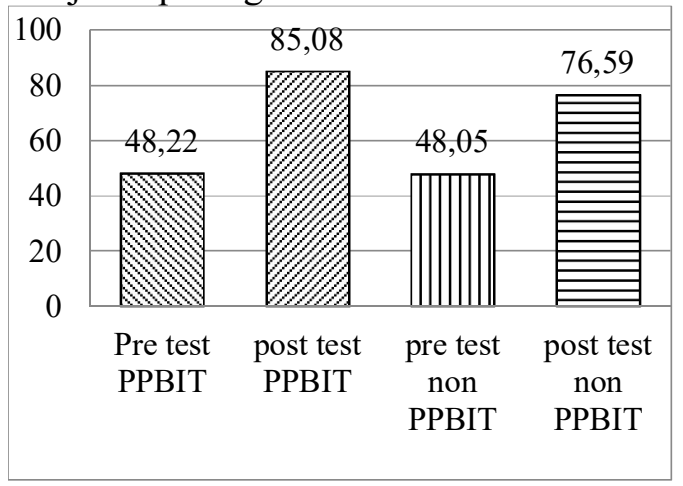

Gambar 4.1 Grafik hasil pretest dan posttes kelas eksperimen dan kelas kontrol

Skor rata-rata $\mathrm{N}$-gain kemampuan berargumen siswa diperoleh hasil sebagai berikut:

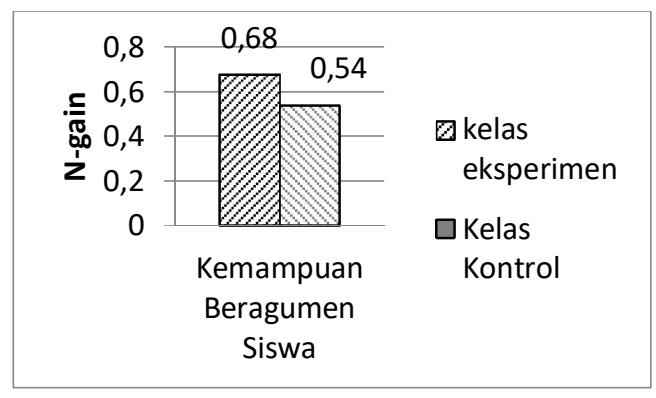

Gambar 4.2 Grafik rata-rata N-Gain kelas eksperimen dan kelas kontrol

Hasil perhitungan $\mathrm{N}$ gain menunjukkan terjadi peningkatan hasil belajar setelah pembelajaran menggunakan PPBIT yaitu 0.68 dibandingkan kelas control dengan perlakuan ceramah dan diskusi yaitu 0.54 .

Hasil uji hipotesis tentang efektifitas penerapan pembelajaran berbasis inkuiti terbimbing (PPBIT) dalam meningkatkan kemampuan berargumen dapat dilihat pada tabel di bawah ini:

Tabel 4.3 Hasil uji hipotesis

\begin{tabular}{lll}
\hline Keterangan & $\mathrm{t}_{\text {hitung }}$ & Sig. \\
\hline $\begin{array}{l}\text { Pre Test Kelas Eksperimen } \\
\text { dan Kelas Kontrol }\end{array}$ & 0,038 & 0,970 \\
\hline $\begin{array}{l}\text { Post Test Kelas Eksperimen } \\
\text { dan Kelas Kontrol }\end{array}$ & 6,218 & 0,000 \\
\hline
\end{tabular}

Berdasarkan hasil uji hipotesis berbunyi penerapan PPBIT efektif dalam meningkatkan kemampuan berargumen siswa, Ha diterima. Artinya bahwa $t_{\text {hitung }}$ (6.218) lebih besar dari tabel $(1,665)$, sehingga kemampuan berargumen siswa yang belajar dengan PPBIT memperoleh skor yang tinggi.

Validitas perangkat PPBIT, dilakukan dengan dua tahapan, (1) validasi tim ahli dan (2) validasi empiris. Hasil uji validitas dari tim ahli terhadap kelayakan silabus diperoleh skor rata-rata sebesar $78.71 \%$, artinya nilai tersebut termasuk dalam kriteria kelayakan tinggi. Produk silabus yang dihasilkan oleh peneliti telah memenuhi kriteria atau langkah-langkah dalam menyusun silabus dan aspek kejelasan isi, kebahasaan dapat digunakan dalam pembelajaran karena sesuai dengan sasaran. Komponen yang dikembangkanpun dalam silabus yaitu pada tujuan 
pembelajaran dan kegiatan pembelajaran yang mengacu pada sintak inkuiri terbimbing. Hasil penelitian ini, sejalan dengan penelitian Ni'mah (2014), bahwa produk silabus yang memenuhi kelayakan baik dapat digunakan dalam pembelajaran.

RPP Inkuiri Terbimbing yang telah disusun diperoleh hasil kelyakan sebesar $83.5 \%$, artinya nilai tersebut telah termasuk dalam kriteria kelayakan sangat tinggi. Kegiatan pembelajaran dari RPP yang dikembangkan dalam penelitian ini terdiri atas beberapa indikator dan telah disesuaikan dengan fase Inkuiri Terbimbing padakegiatan inti pembelajaran, dan digambarkan juga dengan kesesuaian dari penjabaran KD menjadi rumusan indikator yang dapat diukur. Tujuan pembelajaran yang dirumuskan mengarahkan siswa yang mandiri dalam memberdayakan pikirannya yang dituangkan dalam penemuan konsep yang abstrak. Materi pembelajaran memuat fakta dan konsep, prinsip dan prosedur yang dituangkan melalui PKITS yang relevan dan ditulis dalam butir-butir soal sesuai dengan materi pokok dan rumusan indikator. Kelayakan yang diperoleh sejalan dengan penelitian Heriningsih \& Agustini (2014), bahwa penyusunan RPP yang telah sesuai dengan aspek komponen RPP dan kegiatan pembelajaran akan menghasilkan pembelajaran yang efektif.

Validasi empiris ditinjau dari keterlaksanaan pembelajaran inkuiri terbimbing, pemberian tes dan respon siswa terhadap keterlaksanaan dalam pembelajaran. Keterlaksanaan dalam ini pembelajaran menunjukkan presentase yang baik selama pertemuan, yaitu pada pertemuan I persentase $77 \%$, ketercapaian tersebut diperoleh karena siswa masih belum terbiasa dengan model pembelajaran inkuiri terbimbing dan kegiatan pembelajaran masih belum menggali informasi yang terkait dengan pengalaman kehidupan sehari-hari siswa yang berhubungan dengan materi yang diajarkan.

Pertemuan kedua memperoleh presentase $85.5 \%$, siswa sudah mulai aktif karena guru sudah mulai menggali informasi yang terkait dengan pengalaman siswa dengan materi yang disampaikan. Pertemuan ketiga dan keempat sudah terlaksana dengan baik yaitu mencapai 93.8\%. Pembelajaran mengalami peningkatan pada pertemuan-pertemuan berikutnya, hal ini dikarenakan siswa sudah mulai terbiasa dengan model pembelajaran yang diajarkan dan siswa mulai terbiasa dan ekspresi siswa yang bersemangat dalam kegiatan belajar mengajar, hal ini terlihat dari hasil respon siswa yang suka terhadap model pembelajaran ini dan interaksi antara siswa dengan guru, dan antara siswa dengan siswa mulai tercipta, keberanian siswa berbicara untuk mengemukakan serta mempertahankan pendapat tentang ide-ide yang dimiliki terlihat dalam setiap pertemuan.

Hasil validasi PKITS diperoleh skor rata-rata sebesar $75 \%$, artinya nilai tersebut telah termasuk dalam kriteria kelayakan sangat tinggi dan telah dilakukan revisi sesuai dengan saran dari validator. PKITS akan membantu siswa dalam memahami konsep biologi dan mengkonstruksikan pengetahuannya sesuai dengan pengalaman siswa itu sendiri, karena pembelajaran akan lebih efektif apabila siswa dilibatkan langsung dalam kegiatan pembelajaran. Hal ini sesuai dengan pendapat Rustaman (2005), bahwa belajar akan lebih bermakna bagi siswa apabila mereka mendapat kesempatan untuk mengajukan pertanyaan, melaksanakan penyelidikan, dan mengumpulkan data, serta membuat kesimpulan dan berdiskusi.

Hasil validasi instrumen kemampuan berargumen menunjukkan kriteria sangat layak dengan skor yang diperoleh sangat tinggi yaitu $80.25 \%$, Hasil validasi perangkat pembelajaran yang diperoleh, sejalan dengan penelitian Dewi, Sadia, dan Ristiati (2013), bahwa kelayakan perangkat pembelajaran (silabus, RPP, LKS) yang dikembangkan dapat meningkatkan pemahaman siswa dan kinerja ilmiah siswa.

Pembelajaran inkuiri merupakan pembelajaran yang dapat membantu siswa dalam membangun kecakapan berpikir 
terkait dengan proses-proses berpikir yang ditemukan oleh siswa sendiri. Blanchard, Osborne, Walwork \& Harris (2013), menyatakan bahwa jika guru memilki kenyamanan dengan penyelidikan (inkuiri) dan dilaksanakan dengan baik dikelas, maka guru dapat mengoptimalkan hambatan yang dihadapi saat pembelajaran seperti kurangnya semangat dalam belajar, waktu/periode dikelas, waktu perencanaan, dan kepentingan atau kemampuan siswa.

Kemampuan berargumen yang menyatakan hubungan sebab akibat tergambar pada jawaban siswa yaitu siswa dapat menjawab dengan benar, menggambarkan alur berpikir yang logis dan sistematis, dengan bahasa yang baik dan benar. Dalam uraiannya siswa dapat menyatakan sebab dan akibat dari suatu situasi atau konteks persoalan (Suyanik, 2010). Pernyataan yang disampaikan siswa dalam berargumen mengacu pada TAP (Toulmin's Argument Pattern) yang mengelompokkan sifat atau cara berargumen ke dalam enam elemen, yaitu: (1) Claim, (2) data (Grounds), (3) jaminan (Warrant), (4) pendukung (backing), (5) keterangan modalitas (modal qualifier), dan (6) kondisi pengecualian (possible rebuttal). Fungsi guru dalam pembelajaran ini adalah memberikan eksplansi ilmiah dan membantu siswa dalam menemukan alasanalasan yang akan disampaikan dalam berargumen. (Toulmin, dkk (1979) dalam Setianingsih, 2008)

Kemampuan berargumen siswa, sebenarnya sudah dimiliki oleh siswa di dalam dirinya. Kemampuan tersebut belum terbiasa diasah oleh siswa, kemungkinan dikarenakan pembelajaran yang dilakukan selama ini masih bersifat turun temurun, yaitu pembelajaran konvensional seperti ceramah, diskusi yang masih di dominasi dikalangan para guru, sehingga siswa kurang terbiasa dan terlatih dalam mengemukakan pendapat ataupun mengkontruksikan ide-ide yang ada dalam diri siswa untuk dikembangkan.

Siswa masih belum dibebaskan dalam mengekspresikan ide-idenya memecahkan masalah antara konsep dan fakta yang ada dilapangan. Keefektifan hasil pembelajaran inkuiri terbimbing yang diperoleh oleh peneliti sejalan dengan penelitian sebelumnya yang dilakukan oleh Japa dkk (2014), bahwa penerapan model pembelajaran inkuiri terbimbing berpengaruh nyata terhadap keterampilan berpikir kritis dan penelitian Megasari, Achmad, \& Pramudiyanti (2014), bahwa penerapan model pembelajaran inkuiri terbimbing berpengaruh signifikan terhadap kemampuan berpikir kritis siswa.

Siswa yang diberikan PPBIT memiliki kemampuan berargumen yang bagus dalam mengeluarkan ide, mengeluarkan banyak gagasan yang benar, mengkomunikasikan pendapat terhadap konsep yang diterima, siswa sudah mulai berani mengajukan pertanyaan dengan nilai rata-rata yang diperoleh lebih meningkat dibandingkan dengan pembelajaran yang tidak menggunakan PPBIT.

\section{KESIMPULAN}

Berdasarkan hasil penelitiaan dan pembahasan di atas maka dapat ditarik beberapa kesimpulan bahwa Perangkat pembelajaran berorientasi inkuiri terbimbing yang telah dikembangkan layak untuk digunakan dalam pembelajaran biologi, dan efektif untuk meningkatkan kemampuan berargumen siswa SMA Negeri 2 Taliwang-KSB Kelas X Tahun Pelajaran 2014/2015 pada materi pencemaran lingkungan dan daur ulang limbah dibandingkan dengan perangkat pembelajaran yang berorientasi pada ceramah dan diskusi.

\section{DAFTAR PUSTAKA}

Arikunto, S. 2006. Prosedur Penelitian Suatu Pendekatan Praktik. Jakarta: Rineka Cipta, Jakarta

Bell, P \& Linn, M.C. 2007. Scientific Argument as Learning Artifact: Designing For Learning From The web With KLE. International Journal 
of Science. Education, 22(8), 797817. https://scholar. google. o.id/scholar? $\quad h l=\quad i d \& q$ $=$ jurnal + Scientific + Argument + As $+L$ earning + Artifact $+\% 3 A+$ Designing + For + Learning + From + The $+w e b+W i$ th+KLE\&btnG.

Blanchard, M.R., Osborne, J.W., Wallwork, C., \& Harris, E.S. 2013. Progress on Implementing Inquiry in North Carolina: Nearly 1,000 Elementary, Middle and High School Science Teachers Weigh In. International Journal Article Sains Education 2013 VOL. 22, NO. 1. https://www.questia.com> library > Journal.

Dewi, K., Sadia, I. W., \& Ristiati, N.P. Pengembangan Perangkat Pembelajaran IPA Terpadu dengan SettingInkuiri Terbimbing Untuk Meningkatkan Pemahaman Konsep dan Kinerja Ilmiah Siswa. e-jurnal Program Pascasarjana Universitas Ganesha, Volume 3 tahun 2013.https://scholar.google.co.id/sch ola?

$\underline{\text { Start }}=10 \& q=$ jurnal + kemampuan + be rargumen + melalui + inkuiri + terbimbi $\underline{n g \& h l=i d \& a s \_s d t=0,5}$

Eggen \& Kauchak. 2012. Strategis and Models for Teachers. Pearson Education USA

Fisher, A. 2009. Berpikir Kritis. Penerbit Airlangga.

Hussains, A., Azeem, M \& Shakoor, A. 2011. Teaching Methods: Scientific Inquiry $V_{S}$ Traditional Lecture International journal of Humanities and Social Science Vol. 1 No. 19

Heriningsih, D.P \& Agustini R. Pembelajaran Berkarakter Berbasis Inkuiri Untuk Meningkatkan Hasil belajar IPA Siswa SMP. Universitas Negeri Surabaya. Prosiding Seminar
Nasional Kimia, ISSN 2407-9189: 20

September 2014. E. journal. Download.

Portalgaruda.org/article.php.

Japa. L, Ramdani, A., \& Rahmayanti, F. 2014. Pengaruh Penerapan Inkuiri Terbimbing terhadap Kemampuan Berpikir Kritis Siswa Kelas XI Peminatan Matematika dan Ilmu-Ilmu Alam SMAN 2 Gerung. Universitas Mataram.https:// scholar.google.co.id/scholar? start $=1$ $0 \& q=$ jurnal + kemampuan + berargum $\underline{\text { en }+ \text { melalui }+ \text { inkuiri }+ \text { terbimbing } \& h l=}$ id\&as sdt $=0,5$

Megasari, Ahmad, A, Pramudiyanti. 2014. Pengaruh Model Pembelajaran Inkuiri Terbimbing Terhadap Kemampuan Berpikir Kritis. Jurnal Bioterdidik, Vol 2, No. 5 (2014). Universitas Lampung. //jurnal.fkip.unila.ac.id/index.php/jbt/ article/view/3626/

Permendiknas. No. 22. 2006. Standar Isi Untuk Satuan Pendidikan Dasar Menengah, Depdiknas. Jakarta

Programe for International Student Assesment (PISA). 2014. PISA 2012 Results: What Students Know and Can Do Student Performanced In Mathematics, Reading and Science Vol. 1 Revised Edition. OECD, diunduh http://www. oecd.org/PISA/keyfindings/PISA2012-

Riduwan. 2006. Dasar-Dasar Statistik. Penerbit: Alfabeta, Bandung.

Roshayanti, F dan Rustaman, N. 2013. Pengembangan Assesment Argumentatif untuk Meningkatkan Pola Wacana Argumentasi Mahasiswa pada Konsep Fisiologi Manusia. Artikel Bioma Vol 2 No. 1, April 2013 
Rustaman. 2005. Perkembangan Penelitian Pembelajaran Berbasis Inkuiri Dalam Pendidikan Sains. Makalah Dipresentasikan dalam Seminar Nasional II Himpunan Ikatan Sarjana Dan Pemerintah Pendiidkan IPA Indonesia Bekerjasama dengan FPMIPA, Universitas Pendiidkan Indonesia. Bandung 22-23 Juli $2005 . \quad$ https: //scholar.google.co.id/scholar? Start $=10 \& q=$ jurnal + kemampuan + berar gumen + melalui + inkuiri+terbimbin $g \& h l=i d \& a s \quad s d t=0,5$

Setianingsih, Y. 2008. Peningkatan Kemampuan Menulis Argumentatif dan Keterampilan Berpikir Kritis Berbahasa Indonesia Mahasiswa Melalui Model Pembelajaran Berdasarkan Logika Tulmin. Jurnal Educationist, Universitas Sanata Dharma, Yogyakarta. Vol: 2 no. 2 Juli 2008.

Sugiyono. 2009. Statistik untuk Penelitian. Bandung: alfabeta.

Suyanik. 2010. Pengaruh Penerapan Pola Pemberdayaan Berpikir Melalui Pertanyaan (PBMP) Dengan Model Pembelajaran Think Pair Share (TPS) dan Strategi ARIAS terhadap Kemampuan Berpikir Kritis dan Hasil Belajar Kognitif pada Siswa Kelas X SMA Laboratorium Malang. Tesis tidak diterbitkan. Malang: Program Pascasarjana Universitas Negeri Malang.

Trends International Mathematics and ScienceStudent. 2012. TIMSS 2011: Encyclopedia: Education Policy and Curriculum in Mathematics and Science, Volumes 1 and 2. Chestnut Hill, MA: International Study Center, Boston

College.http://timssandpirls.bc.edu/ti mss2011/encyclopedia-timss.html. 